\title{
N-hydroxy-N'-(3,4,5-trimethoxyphenyl)-3,4,5-trimethoxy- benzamidine, a novel resveratrol analog, inhibits ribonucleotide reductase in HL-60 human promyelocytic leukemia cells: Synergistic antitumor activity with arabinofuranosylcytosine
}

\author{
PHILIPP SAIKO $^{1}$, MARIA OZSVAR-KOZMA ${ }^{1}$, ASTRID BERNHAUS ${ }^{1}$, MARGIT JASCHKE ${ }^{1}$, \\ GERALDINE GRASER ${ }^{1}$, ANDREAS LACKNER ${ }^{2}$, MICHAEL GRUSCH ${ }^{2}$, ZSUZSANNA HORVATH $^{3}$, \\ SIBYLLE MADLENER $^{3}$, GEORG KRUPITZA ${ }^{3}$, NORBERT HANDLER ${ }^{4}$, THOMAS ERKER $^{4}$, \\ WALTER JAEGER $^{5}$, MONIKA FRITZER-SZEKERES ${ }^{1}$ and THOMAS SZEKERES ${ }^{1}$
}

${ }^{1}$ Clinical Institute of Medical and Chemical Laboratory Diagnostics, Medical University of Vienna, General Hospital of Vienna, Waehringer Guertel 18-20; ${ }^{2}$ Department of Medicine I, Division of Cancer Research, Medical University of Vienna, Borschkegasse 8a; ${ }^{3}$ Institute of Clinical Pathology, Medical University of Vienna,

Waehringer Guertel 18-20; Departments of ${ }^{4}$ Medicinal Chemistry, and ${ }^{5}$ Clinical Pharmacy and Diagnostics, Faculty of Life Sciences, University of Vienna, Althanstrasse 14, A-1090 Vienna, Austria

Received June 7, 2007; Accepted July 24, 2007

\begin{abstract}
Resveratrol (3,4',5,-trihydroxystilbene, RV), an ingredient of wine, exhibits a broad spectrum of antiproliferative effects against human cancer cells. In order to develop a derivative with comparable effects, we modified the molecule by introducing additional methoxyl groups. The resulting novel RV analog, $N$-hydroxy- $N^{\prime}-(3,4,5-$ trimethoxyphenyl)-3,4,5-trimethoxybenzamidine (KITC), was investigated in HL-60 human promyelocytic leukemia cells. The induction of apoptosis was determined employing a specific Hoechst/propidium iodide double staining method and cell cycle distribution was evaluated by FACS. KITC's influence on the concentration of deoxyribonucleoside triphosphates, the products of ribonucleotide reductase (RR), was determined using the HPLC method. In addition, we analyzed the effects of KITC treatment on the incorporation of ${ }^{14} \mathrm{C}$-cytidine into the DNA of tumor cells in order to quantify the loss of RR in situ activity. To reveal a potential value of KITC for supporting conventional chemotherapy, we also
\end{abstract}

Correspondence to: Dr T. Szekeres, Clinical Institute of Medical and Chemical Laboratory Diagnostics, Medical University of Vienna, General Hospital of Vienna, Waehringer Guertel 18-20, A-1090 Vienna, Austria

E-mail: thomas.szekeres@meduniwien.ac.at

Key words: resveratrol, $N$-hydroxy- $N$-(3,4,5-trimethoxyphenyl)3,4,5-trimethoxybenzamidine, ribonucleotide reductase, arabinofuranosylcytosine, HL-60 human promyelocytic leukemia cells, synergistic combination effects examined whether a combination of KITC with arabinofuranosylcytosine (Ara-C) could yield synergistic growth inhibitory effects. KITC caused a dose-dependent induction of apoptosis, whereas no remarkable changes of the cell cycle distribution were observed. Incubation with KITC resulted in a significant depletion of intracellular dTTP and dATP pools and was also found to remarkably reduce the in situ activity of $\mathrm{RR}$, the key enzyme of de novo DNA synthesis. In addition, KITC exhibited synergistic combination effects when applied sequentially with Ara-C. Due to these promising results, KITC deserves further preclinical and in vivo testing.

\section{Introduction}

Naturally occurring compounds with putative cancer chemopreventive properties, such as the phytoalexin resveratrol (3,4',5-trihydroxy-trans-stilbene; RV), guide the design of novel agents with improved pharmacologic potential. RV displays remarkable cytostatic and cytotoxic activity against a multitude of human cancer cell lines (1-4). RV induces apoptosis via the activation of caspases as well as through the release of mitochondrial cytochrome c $(5,6)$ and was also identified as an effective inhibitor of ribonucleotide reductase (RR). RR catalyzes the rate limiting step of de novo DNA synthesis and is highly upregulated in rapidly proliferating tumor cells in comparison with non-malignant cell populations, which makes the enzyme an excellent target for cancer chemotherapy $(7,8)$. Other clinically established inhibitors of RR, such as hydroxyurea or fludarabine are applied successfully in combination chemotherapy regimens for the treatment of leukemia. These compounds have been proven to exert synergistic effects with the first-line antileukemic agent arabinofuranosylcytosine (Ara-C) (9-14). In addition, $\mathrm{RV}$ has been shown to inhibit DNA polymerase and to arrest 


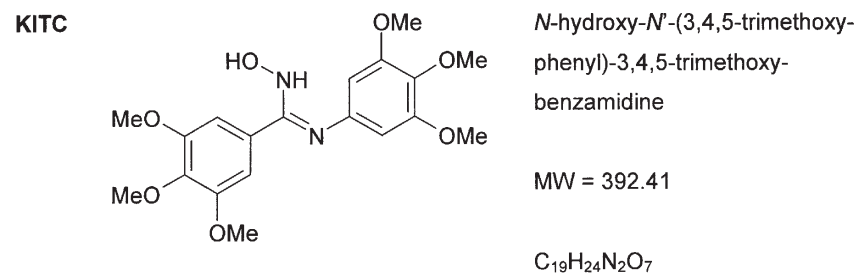

Figure 1. Structural formula of KITC including nomenclature, molecular weight and empirical formula.

cells in the S and G2 phases of the cell cycle (15-19), and to reduce the growth of various myeloma cell lines by a mechanism involving apoptosis (20). RV has been reported to be effective in inhibiting platelet aggregation and lipid peroxidation, altering eicosanoid synthesis, modulating lipoprotein metabolism (21-22), and exhibiting vasorelaxing and anti-inflammatory activities (23). A number of methoxylated $\mathrm{RV}$ derivatives have also displayed remarkable in vitro growth inhibition and apoptotic activity in HL-60 cells (24). MR-4, a tetramethoxystilbene, specifically activated the mitochondriamediated apoptotic pathway in WI38VA cells (25) and was proven to possess even stronger antiproliferative properties than RV in human HCA-7 colon cancer cells (26). Another methoxylated RV molecule, 3,4',5-trimethoxystilbene, exerted cytotoxic effects by depleting the intracellular polyamine pools and by inhibiting tubulin polymerization in Caco-2 cells (27).

In this context, we prepared a series of polymethoxylated RV analogs with the aim of discovering new agents with potential clinical relevance. Here, the antitumor effects of $N$-hydroxy- $N$ '-(3,4,5-trimethoxyphenyl)-3,4,5-trimethoxybenzamidine (KITC) are presented. The activity of KITC was tested in HL-60 human promyelocytic leukemia cells. Its cytotoxicity was evaluated by growth inhibition assays and the induction of apoptosis was determined employing a specific Hoechst/propidium iodide double staining method. Cell cycle distribution after exposure to KITC was investigated by FACS analysis. Since we have shown previously that RV depletes intracellular dNTP concentrations (28), the products of RR, we now investigated whether KITC had comparable effects on dNTP pools. In addition, we analyzed the effects of KITC treatment on the incorporation of ${ }^{14} \mathrm{C}$-cytidine into the DNA of HL-60 cells in order to quantify the loss of RR in situ activity. To determine a potential value of KITC in supporting conventional chemotherapy of human malignancies, we finally examined whether a combination of KITC with Ara-C could yield synergistic growth inhibitory effects in HL-60 cells.

\section{Materials and methods}

Chemicals and supplies. The investigated $N$-hydroxy- $N$ - $(3,4,5-$ trimethoxyphenyl)-3,4,5-trimethoxybenzamidine (KITC) was synthesized and provided by Dr T. Erker, University of Vienna, Austria (structural formula is shown in Fig. 1). All other chemicals and reagents were commercially available (SigmaAldrich, Vienna, Austria) and of the highest purity.

Cell culture. The HL-60 human promyelocytic leukemia cell line was purchased from ATCC (American Type Culture
Collection, Manassas, VA, USA). Cells were grown in RPMI-1640 medium supplemented with $10 \%$ heat inactivated fetal calf serum (FCS), 1\% L-Glutamine and 1\% Penicillinstreptomycin in a humidified atmosphere consisting of $5 \%$ $\mathrm{CO}_{2}$. All media and supplements were obtained from Life Technologies (Paisley, UK). Cell counts were determined using a microcellcounter CC-108 (SYSMEX, Kobe, Japan). Cells in the logarithmic phase of growth were used for all experiments described below.

Growth inhibition assay. HL-60 cells $\left(0.1 \times 10^{6}\right.$ per $\left.\mathrm{ml}\right)$ were seeded in $25-\mathrm{cm}^{2}$ Nunc tissue culture flasks and incubated with increasing concentrations of KITC at $37^{\circ} \mathrm{C}$ under cell culture conditions. Cell counts and $\mathrm{IC}_{50}$ values were determined after $72 \mathrm{~h}$ using the microcellcounter $\mathrm{CC}-108$. The viability of cells was determined by staining with trypan-blue. Results were calculated as number of viable cells.

Hoechst dye 33258 and propidium iodide double staining. The Hoechst staining was performed according to the method described by Grusch and coworkers (29). HL-60 cells $\left(0.4 \times 10^{6}\right.$ per $\mathrm{ml}$ ) were seeded in $25-\mathrm{cm}^{2}$ Nunc tissue culture flasks and exposed to increasing concentrations of KITC for $48 \mathrm{~h}$. Hoechst 33258 (HO, Sigma, St. Louis, MO, USA) and propidium iodide (PI, Sigma) were added directly to the cells to final concentrations of 5 and $2 \mu \mathrm{g} / \mathrm{ml}$, respectively. After $60 \mathrm{~min}$ of incubation at $37^{\circ} \mathrm{C}$, cells were examined on a Leica DMR XA fluorescence microscope (Leica, Wetzlar, Germany) equipped with appropriate filters for Hoechst 33258 and PI. This method allows to distinguish between early apoptosis, late apoptosis, and necrosis. Cells were judged according to their morphology and the integrity of their cell membranes, which can easily be seen after propidium iodide staining. Cells were counted under the microscope (150 cells per flask) and the number of apoptotic cells was given as percentage value.

Cell-cycle distribution analysis. HL-60 cells $\left(0.4 \times 10^{6}\right.$ per $\left.\mathrm{ml}\right)$ were seeded in $25-\mathrm{cm}^{2}$ Nunc tissue culture flasks and incubated with increasing concentrations of KITC at $37^{\circ} \mathrm{C}$ under cell culture conditions. After $24 \mathrm{~h}$, cells were harvested and suspended in $5 \mathrm{ml}$ cold PBS, centrifuged, resuspended and fixed in $3 \mathrm{ml}$ cold ethanol (70\%) for $30 \mathrm{~min}$ at $4^{\circ} \mathrm{C}$. After two washing steps in cold PBS RNAse A and propidium iodide were added to a final concentration of $50 \mu \mathrm{g} / \mathrm{ml}$ each and incubated at $4^{\circ} \mathrm{C}$ for 60 min before measurement. Cells were analyzed on a FACSCalibur flow cytometer (BD Biosciences, San Jose, CA, USA) and cell-cycle distribution was calculated with ModFit LT software (Verity Software House, Topsham, ME, USA).

Determination of deoxyribonucleoside triphosphates (dNTPs). Logarithmically growing HL-60 $\left(0.4 \times 10^{6}\right.$ cells per ml $)$ cells were incubated with 25, 50, and $100 \mu \mathrm{M}$ KITC for $24 \mathrm{~h}$. Afterwards, $5 \times 10^{7}$ cells were separated for the extraction of dNTPs according to the method described by Garrett and Santi (30). Cells were centrifuged at $1800 \mathrm{rpm}$ for $5 \mathrm{~min}$ and then resuspended in $100 \mu 1$ phosphate-buffered saline. In this suspension, cells were lysed by addition of $10 \mu 1$ of trichloroacetic acid and the mixture was vortexed for $1 \mathrm{~min}$. The lysate 


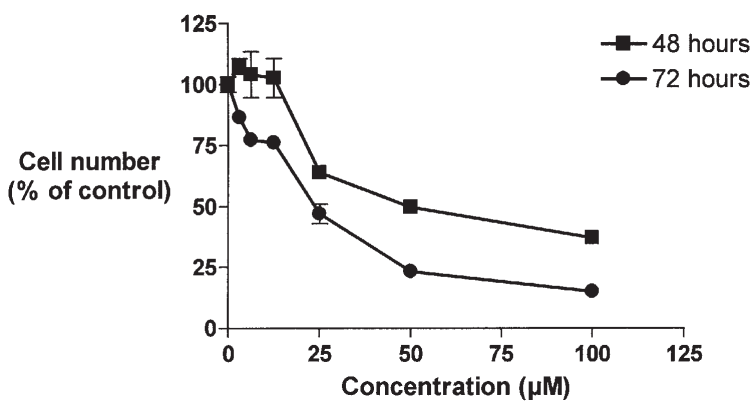

Figure 2. Growth inhibition of human HL-60 promyelocytic leukemia cells after incubation with KITC for 48 and $72 \mathrm{~h}$. HL-60 cells $\left(0.1 \times 10^{6}\right.$ per ml $)$ were seeded in $25-\mathrm{cm}^{2}$ Nunc tissue culture flasks and incubated with increasing concentrations of KITC at $37^{\circ} \mathrm{C}$ under cell culture conditions. Cell counts and $\mathrm{IC}_{50}$ values were determined using the microcellcounter CC-108. Viability of cells was determined by trypan-blue staining. Results were calculated as number of viable cells. Data are means \pm standard errors of three determinations of one representative experiment.

was rested on ice for $30 \mathrm{~min}$ and then the protein was separated by centrifugation at $15000 \mathrm{rpm}$ for $10 \mathrm{~min}$ in an Eppendorf microcentrifuge. The supernatant was removed and neutralized by adding $1.1 \mathrm{vol}$ of Freon containing $0.5 \mathrm{M}$ tri-n-octylamin. Aliquots of $100 \mu 1$ were periodated by adding $30 \mu 1$ of $4 \mathrm{M}$ methylamine solution and $10 \mu \mathrm{l}$ sodium periodate solution (concentration: $100 \mathrm{~g} / \mathrm{l}$ ). After incubation at $37^{\circ} \mathrm{C}$ for $30 \mathrm{~min}$, the reaction was stopped by adding $5 \mu \mathrm{l}$ of $1 \mathrm{M}$ rhamnose solution. The extracted dNTPs were measured using a Merck 'La Chrom' HPLC system equipped with L-7200 autosampler, L-7100 pump, L-7400 UV detector, and D-7000 interface. Samples were eluted with a $3.2 \mathrm{M}$ ammonium phosphate buffer, $\mathrm{pH} 3.4$ ( $\mathrm{pH}$ adjusted by addition of $0.32 \mathrm{~mol} / 1 \mathrm{H}_{3} \mathrm{PO}_{4}$ ), containing $20 \mathrm{mM}$ acetonitrile using a $4.6 \times 250 \mathrm{~mm}$ Partisil 10 SAX analytical column (Whatman, Kent, UK). Separation was performed at constant ambient temperature with a flow rate of $2 \mathrm{ml} / \mathrm{min}$. The concentration of dNTPs was calculated as percent of total area under the curve for each sample. Intracellular concentrations of dNTPs in untreated control cells were 4.96, 24.52, and 7.22 $\mu \mathrm{M}$ for dCTP, dTTP, and dATP, respectively.

Incorporation of ${ }^{14} \mathrm{C}$-labelled cytidine into DNA. To analyze the effect of KITC incubation on the activity of DNA synthesis, an assay was performed as described previously (31). Logarithmically growing HL-60 cells $\left(0.4 \times 10^{6}\right.$ cells per ml $)$ were incubated with various concentrations of KITC for $24 \mathrm{~h}$. After incubation, cells were counted and pulsed with ${ }^{14} \mathrm{C}$-cytidine $(0.3125 \mu \mathrm{Ci}, 5 \mathrm{nM})$ for $30 \mathrm{~min}$ at $37^{\circ} \mathrm{C}$. Afterwards, cells were collected by centrifugation and washed with PBS. Total DNA was extracted from $5 \times 10^{6}$ cells and specific radioactivity of the samples was determined using a Wallac 1414 liquid scintillation counter (Perkin-Elmer, Boston, MA).

Sequential growth inhibition assay using KITC and Ara-C. Employing a sequential growth inhibition assay, HL-60 cells $\left(0.1 \times 10^{6}\right.$ per $\left.\mathrm{ml}\right)$ were first incubated with different concentrations of $\operatorname{KITC}(5,10$, and $20 \mu \mathrm{M})$ for $24 \mathrm{~h}$. Then KITC was washed out and cells were further exposed to various concentrations of Ara-C (5, 10, and $15 \mathrm{nM})$ for another

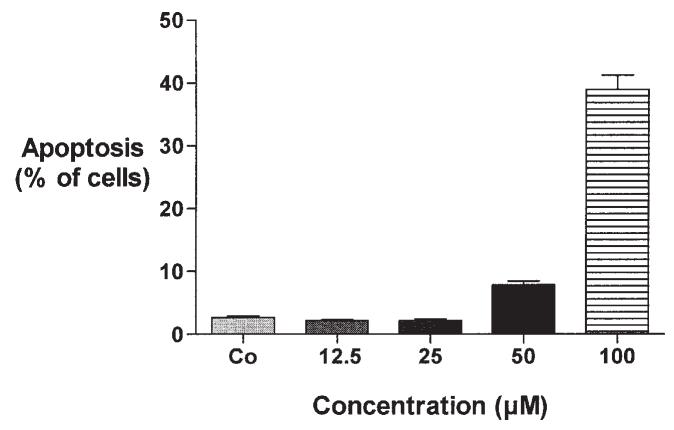

Figure 3. Induction of apoptosis in human HL-60 promyelocytic leukemia cells after incubation with KITC for $48 \mathrm{~h}$. HL- 60 cells $\left(0.4 \times 10^{6}\right.$ per ml) were seeded in $25-\mathrm{cm}^{2}$ Nunc tissue culture flasks and exposed to increasing concentrations of KITC for 48 h. Hoechst 33258 (HO, Sigma, St. Louis, MO, USA) and propidium iodide (PI, Sigma) were added directly to the cells to final concentrations of 5 and $2 \mu \mathrm{g} / \mathrm{ml}$, respectively. After $60 \mathrm{~min}$ of incubation at $37^{\circ} \mathrm{C}$, cells were counted under a fluorescence microscope and the number of apoptotic cells was given as percentage value. Data are means \pm standard errors of three determinations of one representative experiment.

$48 \mathrm{~h}$, always using a constant combination ratio. After that period, cells were counted using a microcellcounter CC-108.

Statistical calculations. Dose-response curves were calculated using the Prism 4.03 software package (GraphPad, San Diego, CA, USA) and statistical significance was determined by unpaired t-test. The calculations of dose response curves and combination effects were performed using the Calcusyn software designed by Chou and Talalay (Biosoft, Ferguson, MO) (32).

\section{Results}

Effect of KITC on the growth of HL-60 human promyelocytic leukemia cells. Logarithmically growing HL-60 cells were incubated with increasing concentrations of KITC. After 48 and $72 \mathrm{~h}$ of incubation, KITC inhibited the growth of tumor cells with $\mathrm{IC}_{50}$ values of 49 and $23 \mu \mathrm{M}$, respectively. Results are depicted in Fig. 2.

Induction of apoptosis in HL-60 human promyelocytic leukemia cells by KITC. HL-60 cells were incubated with $12.5,25,50$, and $100 \mu \mathrm{M}$ KITC for $48 \mathrm{~h}$. Then cells were double stained with Hoechst 33258 and propidium iodide as described in the methods section. After the incubation period, the morphology of HL-60 cells showed nuclear condensation and fragmentation (early apoptosis) as well as signs of late apoptosis with membrane damage and incorporation of propidium iodide. As seen in Fig. 3, induction of apoptosis was dose dependent with up to $39 \%$ of cells showing hallmarks of apoptosis at $100 \mu \mathrm{M}$ KITC.

Cell-cycle distribution in HL-60 human promyelocytic leukemia cells after treatment with KITC. HL-60 cells were prepared as described in the methods section and incubated with increasing concentrations of KITC for $24 \mathrm{~h}$. Up to a concentration of $400 \mu \mathrm{M}$, no remarkable changes of the cell cycle phase distribution were observed. Growth arrest after treatment with $400 \mu \mathrm{M}$ KITC occurred mainly in the G0-G1 phase, increasing 


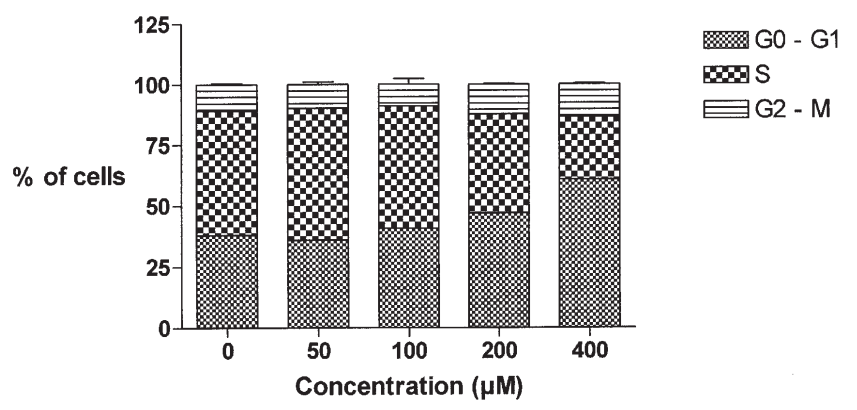

Figure 4. Cell cycle distribution in human HL-60 promyelocytic leukemia cells after incubation with KITC for $24 \mathrm{~h}$. HL- 60 cells $\left(0.4 \times 10^{6}\right.$ per ml) were seeded in $25-\mathrm{cm}^{2}$ Nunc tissue culture flasks and incubated with increasing concentrations of KITC at $37^{\circ} \mathrm{C}$ under cell culture conditions. Cells were analyzed on a FACSCalibur flow cytometer (BD Biosciences, San Jose, CA, USA) and cell cycle distribution was calculated with ModFit LT software (Verity Software House, Topsham, ME, USA). Data are means \pm standard errors of three determinations of one representative experiment.

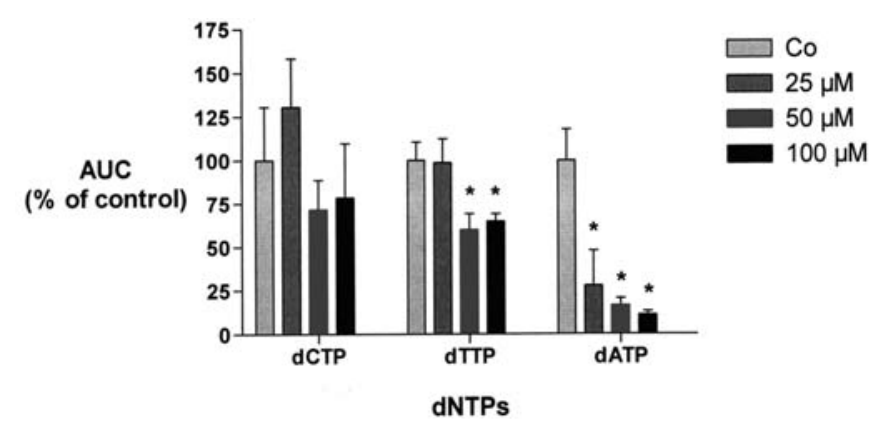

Figure 5. Concentration of deoxyribonucleoside triphosphate (dNTP) pools in human HL-60 promyelocytic leukemia cells after treatment with KITC for $24 \mathrm{~h}$. Logarithmically growing HL-60 cells $\left(0.4 \times 10^{6}\right.$ cells per $\left.\mathrm{ml}\right)$ were incubated with 25,50 , and $100 \mu \mathrm{M}$ KITC for $24 \mathrm{~h}$. Afterwards, $5 \times 10^{7}$ cells were separated for the extraction of dNTPs. The concentration of dNTPs was calculated as percent of total area under the curve for each sample. Intracellular concentrations of dNTPs in untreated control cells were 4.96, 24.52 , and 7.22 $\mu \mathrm{M}$ for dCTP, dTTP, and dATP, respectively. Data are means \pm standard errors of three determinations of one representative experiment. ${ }^{*}$ Values significantly $(\mathrm{p}<0.05)$ different from control.

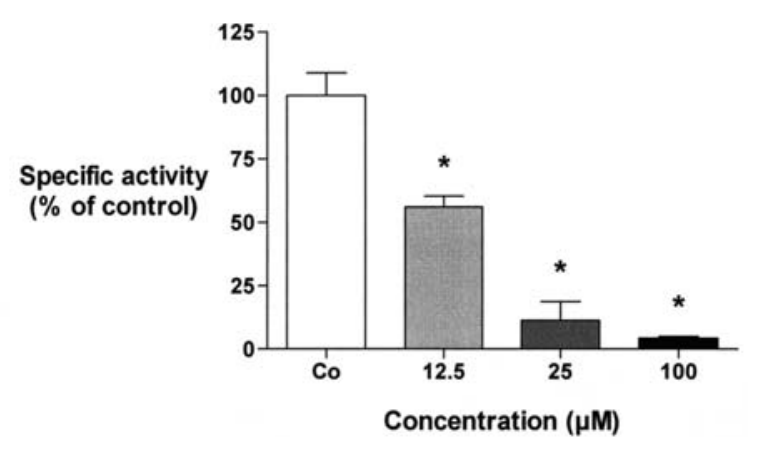

Figure 6. In situ measurement of ribonucleotide reductase (RR) activity in human HL-60 promyelocytic leukemia cells after incubation with KITC for $24 \mathrm{~h}$. Logarithmically growing HL-60 cells $\left(0.4 \times 10^{6}\right.$ cells per $\left.\mathrm{ml}\right)$ were incubated with increasing concentrations of KITC for $24 \mathrm{~h}$. After the incubation period, cells were counted and pulsed with ${ }^{14} \mathrm{C}$-cytidine $(0.3125 \mu \mathrm{Ci}$, $5 \mathrm{nM}$ ) for $30 \mathrm{~min}$ at $37^{\circ} \mathrm{C}$. Then cells were collected by centrifugation and washed with PBS. Total DNA was extracted from $5 \times 10^{6}$ cells and specific radioactivity of the samples was determined using a Wallac 1414 liquid scintillation counter (Perkin-Elmer, Boston, MA). Data are means \pm standard errors of two determinations of one representative experiment. *Values significantly $(\mathrm{p}<0.05)$ different from control. the cell population from $38 \%$ to $61 \%$. Simultaneously, cells in the $\mathrm{S}$ phase were decreased from $51 \%$ to $26 \%$. Results are summarized in Fig. 4.

Effect of KITC on deoxyribonucleoside triphosphates (dNTPs) in HL-60 cells. HL-60 cells were incubated with 25, 50 , and $100 \mu \mathrm{M}$ of KITC for $24 \mathrm{~h}$. Then dNTP pool sizes were determined using the HPLC method described in the methods section. KITC treatment caused a remarkable imbalance of dNTPs in HL-60 cells. Incubation of cells with 50 and $100 \mu \mathrm{M}$ KITC for $24 \mathrm{~h}$ resulted in a depletion of intracellular dCTP, dTTP, and dATP pools. Treatment with $50 \mu \mathrm{M}$ KITC significantly decreased dTTP and dATP pools to $60 \%$ and $16 \%$ of control values, respectively. In contrast, $25 \mu \mathrm{M}$ KITC led to an increase of the dCTP pool to $130 \%$ of control values, while decreasing the dATP pool to $27 \%$ of controls. After incubation with $100 \mu \mathrm{M}$ KITC for $24 \mathrm{~h}$, dTTP and dATP pools were again significantly decreased when compared with untreated controls. All dGTP pools remained beyond the detectability of the method. Results are shown in Fig. 5.

Inhibition of incorporation of ${ }^{14} \mathrm{C}$-cytidine into DNA. Incorporation of ${ }^{14} \mathrm{C}$-cytidine into the DNA of HL-60 cells was determined after incubation with KITC. After treatment of HL-60 cells with $12.5,25$, and $100 \mu \mathrm{M}$ KITC for $24 \mathrm{~h},{ }^{14} \mathrm{C}$ cytidine incorporation into DNA was significantly decreased to $56 \%, 11.5 \%$, and $4.3 \%$ of control values, respectively. Results are depicted in Fig. 6.

Synergistic combination effects of KITC and Ara-C on the growth of HL-60 cells. Logarithmically growing HL-60 cells were seeded at a concentration of $0.1 \times 10^{6}$ per $\mathrm{ml}$ and incubated with increasing concentrations of drugs. Eight out of nine combinations applied $(5,10$, and $20 \mu \mathrm{M}$ KITC combined with 5,10 , and $15 \mathrm{nM}$ Ara-C, respectively) yielded synergistic combination effects according to the equation of Chou and Talalay. All data are summarized in Table I.

\section{Discussion}

Increased cell proliferation and decreased cell death (by means of apoptosis) are two major processes that contribute to the progression of cancer cell growth. Consequently, new agents that can inhibit cell proliferation and/or induce apoptosis are of great therapeutic value. Resveratrol $(3,4$ ',5trihydroxystilbene; RV) is a naturally occurring polyphenolic compound found in grapes, wine and various medical plants. Numerous studies have revealed that RV exerts remarkable antioxidant, anti-inflammatory, and anti-tumor activities as well as demonstrating a preventive effect for cancer. RV was proven to inhibit ribonucleotide reductase (RR) which is the rate-limiting enzyme for de novo DNA synthesis and therefore considered an excellent target for cancer chemotherapy. Balanced deoxyribonucleoside triphosphate (dNTP) concentrations are essential for DNA synthesis, especially in rapidly proliferating tumor cells. Various inhibitors of RR, such as hydroxyurea or difluorodeoxycytidine (Gemcitabine, $\mathrm{dFdC}$ ), are commonly used for the treatment of various human malignancies. 
Table I. Synergistic combination effects of KITC and Ara-C in human HL-60 promyelocytic leukemia cells employing a sequential growth inhibition assay.

\begin{tabular}{|c|c|c|c|c|}
\hline Compound & Concentration $(\mu \mathrm{M} / \mathrm{nM})$ & Cell number ( $\%$ of control) & Predicted value ${ }^{\mathrm{a}}$ & Combination index ${ }^{b}$ \\
\hline $\begin{array}{l}\text { KITC (A) } \\
(\mu \mathrm{M})\end{array}$ & $\begin{array}{r}5 \\
10 \\
20\end{array}$ & $\begin{array}{l}88.2 \\
57.8 \\
58.2\end{array}$ & & \\
\hline $\begin{array}{l}\text { Ara-C (B) } \\
(\mathrm{nM})\end{array}$ & $\begin{array}{r}5 \\
10 \\
15\end{array}$ & $\begin{array}{l}76.2 \\
67.0 \\
60.5\end{array}$ & & \\
\hline $\begin{array}{l}\text { KITC } \\
+ \text { Ara-C }\end{array}$ & $\begin{array}{l}5 \\
5\end{array}$ & 55.2 & 67.2 & $0.525^{\mathrm{c}}$ \\
\hline $\begin{array}{l}\text { KITC } \\
+ \text { Ara-C }\end{array}$ & $\begin{array}{r}5 \\
10\end{array}$ & 50.6 & 59.1 & $0.608^{c}$ \\
\hline $\begin{array}{l}\text { KITC } \\
+ \text { Ara-C }\end{array}$ & $\begin{array}{r}5 \\
15\end{array}$ & 38.1 & 53.4 & $0.417^{\mathrm{c}}$ \\
\hline $\begin{array}{l}\text { KITC } \\
+ \text { Ara-C }\end{array}$ & $\begin{array}{r}10 \\
5\end{array}$ & 41.3 & 44.2 & $0.465^{\mathrm{c}}$ \\
\hline $\begin{array}{l}\text { KITC } \\
+ \text { Ara-C }\end{array}$ & $\begin{array}{l}10 \\
10\end{array}$ & 37.7 & 38.8 & $0.483^{c}$ \\
\hline $\begin{array}{l}\text { KITC } \\
+ \text { Ara-C }\end{array}$ & $\begin{array}{l}10 \\
15\end{array}$ & 38.1 & 35.1 & \\
\hline $\begin{array}{l}\text { KITC } \\
+ \text { Ara-C }\end{array}$ & $\begin{array}{r}20 \\
5\end{array}$ & 38.1 & 44.4 & $0.730^{\mathrm{c}}$ \\
\hline $\begin{array}{l}\text { KITC } \\
+ \text { Ara-C }\end{array}$ & $\begin{array}{l}20 \\
10\end{array}$ & 35.1 & 39.0 & $0.720^{c}$ \\
\hline $\begin{array}{l}\text { KITC } \\
+ \text { Ara-C }\end{array}$ & $\begin{array}{l}20 \\
15\end{array}$ & 33.5 & 35.2 & $0.736^{c}$ \\
\hline
\end{tabular}

Cells were sequentially incubated with KITC $(24 \mathrm{~h})$ and Ara-C $(48 \mathrm{~h})$, and then cell count was determined. Data are means of three

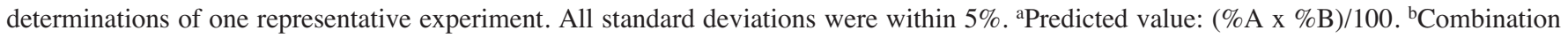
indices according to the equation of Chou and Talalay (32). 'Synergistic combination effect.

In this context, we prepared a series of polymethoxylated RV analogs with the aim of discovering new agents with potential clinical relevance. One of these derivatives is KITC, which proved to be a potent inhibitor of RR, resulting in a significant alteration of dNTP pool balance. Due to this effect, DNA synthesis in rapidly growing cancer cells is blocked and cell cycle perturbations and/or induction of apoptosis are the consequence. After $72 \mathrm{~h}$ of incubation, KITC inhibited the growth of tumor cells with an $\mathrm{IC}_{50}$ value of $23 \mu \mathrm{M}$. Although RV was found to be a more potent inhibitor of RR by causing depletion of all dNTP pools in HL-60 cells (28), KITC possesses a slightly different profile based on its effects on intracellular dNTP concentrations. Incubation with 50 or $100 \mu \mathrm{M}$ KITC caused a significant decrease in intracellular dTTP and dATP pools while the amount of dGTP remained beyond the detectability of the method. In particular, a similar depletion of dATP pool sizes could previously be observed with Gemcitabine $(9,33)$, a mechanism mainly contributing to the antitumor properties of this clinically established anticancer drug. By causing such an imbalance on the concentration of precursors of de novo DNA synthesis, KITC was expected to cause programmed cell death by means of apoptosis and/or to interfere with cell cycle progression. Using a specific double staining method, we indeed found that incubation with KITC led to a dose-dependent induction of apoptosis. However, KITC seems not to exert any influence on the cell cycle distribution of HL-60 cells as a remarkable arrest in the G0/G1 phase could only be observed after treatment with $400 \mu \mathrm{M}$ of the drug. Since RV has been identified to act in a synergistic manner when applied in combination with Ara-C (28), we finally tested whether KITC could also synergistically potentiate the cytostatic effects of Ara-C. As shown above, KITC depleted intracellular dTTP and dATP pools, while Ara-C is metabolized to Ara-CTP before being incorporated into DNA. We therefore suggested that a combined treatment with these two agents could lead to synergistic antitumor activity. Indeed, using a sequential combination of KITC and Ara-C, eight out of nine concentrations applied yielded combination indices $<1$, 
indicating synergism according to the equation of Chou and Talalay (32). Due to these promising results, KITC may support conventional chemotherapy of human malignancies and therefore deserves further preclinical and in vivo testing.

\section{References}

1. Pozo-Guisado E, Alvarez-Barrientos A, Mulero-Navarro S, Santiago-Josefat B and Fernandez-Salguero PM: The antiproliferative activity of resveratrol results in apoptosis in MCF-7 but not in MDA-MB-231 human breast cancer cells: cell-specific alteration of the cell cycle. Biochem Pharmacol 64: 1375-1386, 2002.

2. Zhou HB, Yan Y, Sun YN and Zhu JR: Resveratrol induces apoptosis in human esophageal carcinoma cells. World J Gastroenterol 9: 408-411, 2003.

3. Ferry-Dumazet H, Garnier O, Mamani-Matsuda M, Vercauteren J, Belloc F, Billiard C, Dupouy M, Thiolat D, Kolb JP, Marit G, Reiffers J and Mossalayi MD: Resveratrol inhibits the growth and induces the apoptosis of both normal and leukemic hematopoietic cells. Carcinogenesis 23: 1327-1333, 2002.

4. Mouria M, Gukovskaya AS, Jung Y, Buechler P, Hines OJ, Reber HA and Pandol SJ: Food-derived polyphenols inhibit pancreatic cancer growth through mitochondrial cytochrome $\mathrm{C}$ release and apoptosis. Int J Cancer 98: 761-769, 2002.

5. Clement MV, Hirpara JL, Chawdhury SH and Perviaz S: Chemopreventive agent resveratrol, a natural product derived from grapes, triggers CD 95 signaling-dependent apoptosis in human tumor cells. Blood 92: 996-1002, 1998.

6. Dorrie J, Gerauer H, Wachter Y and Zunino SJ: Resveratrol induces extensive apoptosis by depolarizing mitochondrial membranes and activating caspase- 9 in acute lymphoblastic leukemia cells. Cancer Res 61: 4731-4739, 2001.

7. Fontecave M, Lepoivre M, Elleingand E, Gerez C and Guittet O: Resveratrol, a remarkable inhibitor of ribonucleotide reductase. FEBS Lett 421: 277-279, 1998.

8. Elford HL, Freese M, Passamani E and Morris HP: Ribonucleotide reductase and cell proliferation. I. Variations of ribonucleotide reductase activity with tumor growth rate in a series of rat hepatomas. J Biol Chem 245: 5228-5233, 1970.

9. Gandhi V, Estey E and Plunkett W: Modulation of arabinosylcytosine metabolism during leukemia therapy. Adv Exp Med Biol 370: 119-124, 1994.

10. Gandhi V and Plunkett W: Modulatory activity of $2^{\prime}, 2^{\prime}-$ difluorodeoxycytidine on the phosphorylation and cytotoxicity of arabinosyl nucleosides. Cancer Res 50: 3675-3680, 1990.

11. Gandhi V, Kemena A, Keating MJ and Plunkett W: Fludarabine infusion potentiates arabinosylcytosine metabolism in lymphocytes of patients with chronic lymphocytic leukemia. Cancer Res 52: 897-903, 1992.

12. Gandhi V, Estey E, Keating MJ and Plunkett W: Fludarabine potentiates metabolism of cytarabine in patients with acute myelogenous leukemia during therapy. J Clin Oncol 11: 116-124, 1993.

13. Jackson G, Taylor P, Smith GM, Marcus R, Smith A, Chu P, Littlewood TJ, Duncombe A, Hutchinson M, Mehta AB, Johnson SA, Carey P, MacKie MJ, Ganly PS, Turner GE, Deane M, Schey S, Brookes J, Tollerfield SM and Wilson MP: A multicentre, open, non-comparative phase II study of a combination of fludarabine phosphate, cytarabine and granulocyte colony-stimulating factor in relapsed and refractory acute myeloid leukaemia and de novo refractory anaemia with excess of blasts in transformation. Br J Haematol 112: 127-137, 2001.

14. Nandy P, Lien EJ and Avramis VI: Inhibition of ribonucleotide reductase by a new class of isoindole derivatives: drug synergism with cytarabine (Ara-C) and induction of cellular apoptosis. Anticancer Res 19: 1625-1633, 1999.

15. Stivala LA, Savio M, Carafoli F, Perucca P, Bianchi L, Maga G, Forti L, Pagnoni UM, Albini A, Prosperi E and Vannini V: Specific structural determinants are responsible for the antioxidant activity and the cell cycle effects of resveratrol. J Biol Chem 276: 22586-22594, 2001.

16. Hsieh TC, Juan G, Darzynkiewicz Z and Wu JM: Resveratrol increases nitric oxide synthase, induces accumulation of p53 and p21 (WAF1/CIP1), and suppresses cultured bovine pulmonary artery endothelial cell proliferation by perturbing progression through S and G2. Cancer Res 59: 2596-2601, 1999.
17. Estrov Z, Shishodia S, Faderl S, Harris D, Van Q, Kantarjian HM, Talpaz $M$ and Aggarwal BB: Resveratrol blocks interleukin-1 beta-induced activation of the nuclear transcription factor NFkappaB, inhibits proliferation, causes S-phase arrest, and induces apoptosis of acute myeloid leukemia cells. Blood 102: 987-995, 2003.

18. Ragione FD, Cucciolla V, Borriello A, Pietra VD, Racioppi L, Soldati G, Manna C, Galletti P and Zappia V: Resveratrol arrests the cell division cycle at $\mathrm{S} / \mathrm{G} 2$ phase transition. Biochem Biophys Res Commun 250: 53-58, 1998.

19. Bernhard D, Tinhofer I, Tonko M, Hubl H, Ausserlechner MJ, Greil R, Kofler R and Csordas A: Resveratrol causes arrest in the S-phase prior to Fas-independent apoptosis in CEM-C7H2 acute leukemia cells. Cell Death Differ 7: 834-842, 2000.

20. Boissy P, Andersen TL, Abdallah BM, Kassem M, Plesner T and Delaisse JM: Resveratrol inhibits myeloma cell growth, prevents osteoclast formation, and promotes osteoblast differentiation. Cancer Res 65: 9943-9952, 2005.

21. Kimura Y, Okuda H and Arichi S: Effects of stilbenes on arachidonate metabolism in leukocytes. Biochim Biophys Acta 834: 275-278, 1985.

22. Chung MI, Teng CM, Cheng KL, Ko FN and Lin CN: An antiplatelet principle of Veratrum formosanum. Planta Med 58: 274-276, 1992.

23. Pace-Asciak CR, Hahn S, Diamandis EP, Soleas G and Goldberg DM: The red wine phenolics trans-resveratrol and quercetin block human platelet aggregation and eicosanoid synthesis: implications for protection against coronary heart disease. Clin Chim Acta 235: 207-219, 1995.

24. Roberti M, Pizzirani D, Simoni D, Rondanin R, Baruchello R, Bonora C, Buscemi F, Grimaudo S and Tolomeo M: Synthesis and biological evaluation of resveratrol and analogues as apoptosis-inducing agents. J Med Chem 46: 3546-3554, 2003.

25. Gosslau A, Chen M, Ho CT and Chen KY: A methoxy derivative of resveratrol analogue selectively induced activation of the mitochondrial apoptotic pathway in transformed fibroblasts. Br J Cancer 92: 513-521, 2005.

26. Sale S, Tunstall RG, Ruparelia KC, Potter GA, Steward WP, and Gescher AJ: Comparison of the effects of the chemopreventive agent resveratrol and its synthetic analog trans $3,4,5,4$ 'tetramethoxystilbene (DMU-212) on adenoma development in the Apc(Min+) mouse and cyclooxygenase-2 in human-derived colon cancer cells. Int J Cancer 115: 194-201, 2005.

27. Schneider Y, Chabert P, Stutzmann J, Coelho D, Fougerousse A, Gosse F, Launay JF, Brouillard R and Raul F: Resveratrol analog (Z)-3,5,4'-trimethoxystilbene is a potent anti-mitotic drug inhibiting tubulin polymerization. Int J Cancer 107: 189-196, 2003.

28. Horvath Z, Saiko P, Illmer C, Madlener S, Hoechtl T, Bauer W, Erker T, Jaeger W, Fritzer-Szekeres M and Szekeres T: Synergistic action of resveratrol, an ingredient of wine, with Ara-C and tiazofurin in HL-60 human promyelocytic leukemia cells. Exp Hematol 33: 329-335, 2005

29. Grusch M, Polgar D, Gfatter S, Leuhuber K, Huettenbrenner S, Leisser C, Fuhrmann G, Kassie F, Steinkellner H, Smid K, Peters GJ, Jayaram HN, Klepal W, Szekeres T, Knasmuller S and Krupitza G: Maintenance of ATP favours apoptosis over necrosis triggered by benzamide riboside. Cell Death Differ 9: 169-178, 2002.

30. Garrett C and Santi DV: A rapid and sensitive high pressure liquid chromatography assay for deoxyribonucleoside triphosphates in cell extracts. Anal Biochem 99: 268-273, 1979.

31. Szekeres T, Gharehbaghi K, Fritzer M, Woody M, Srivastava A, van't Riet B, Jayaram HN and Elford HL: Biochemical and antitumor activity of trimidox, a new inhibitor of ribonucleotide reductase. Cancer Chemother Pharmacol 34: 63-66, 1994.

32. Chou TC and Talalay P: Quantitative analysis of dose-effect relationships: the combined effects of multiple drugs or enzyme inhibitors. Adv Enzyme Regul 22: 27-55, 1984.

33. Robinson BW, Im MM, Ljungman M, Praz F and Shewach DS: Enhanced radiosensitization with gemcitabine in mismatch repair-deficient HCT116 cells. Cancer Res 63: 6935-6941, 2003. 